Man and Nature

L'homme et la nature

\title{
Towards an Histrionic Aesthetics: Diderot's Paradoxe as Pre-text for Romantic Irony
}

\section{Judith Spencer}

Volume 7, 1988

URI : https://id.erudit.org/iderudit/1011932ar

DOI : https://doi.org/10.7202/1011932ar

Aller au sommaire du numéro

Éditeur(s)

Canadian Society for Eighteenth-Century Studies / Société canadienne d'étude du dix-huitième siècle

ISSN

0824-3298 (imprimé)

1927-8810 (numérique)

Découvrir la revue

Citer cet article

Spencer, J. (1988). Towards an Histrionic Aesthetics: Diderot's Paradoxe as Pre-text for Romantic Irony. Man and Nature / L'homme et la nature, 7, 149-158. https://doi.org/10.7202/1011932ar

Copyright (c) Canadian Society for Eighteenth-Century Studies / Sociéte canadienne d'étude du dix-huitième siècle, 1988
Ce document est protégé par la loi sur le droit d'auteur. L'utilisation des services d'Érudit (y compris la reproduction) est assujettie à sa politique d'utilisation que vous pouvez consulter en ligne.

https://apropos.erudit.org/fr/usagers/politique-dutilisation/ 


\section{Towards an Histrionic Aesthetics: Diderot's Paradoxe as Pre-text for Romantic Irony}

The Eighteenth Century is commonly construed as an age which repudiated the transcendent, whether in the realm of politics, religion or literature. Indeed, the freedom of negativity may be considered as the diabolical privilege of that era. What we propose in this paper is an analysis of the implications of this spirit of negativity as it relates to the aesthetic artifact. 'La litterrature,' writes Sartre à propos of the Eighteenth Century, 'se confond avec la négativité, c'est-à-dire avec le doute, le refus, la critique, la contestation. ${ }^{1} 1$ The raison d'être and the modus operandi of this literature of contestation will be the focus of our paper: the affinities between Diderot's Paradoxe sur le comédien and the concept of Romantic Irony constitute its parameters. What interests us in Diderot's Paradoxe is not so much the contemporary understanding of the text, ${ }^{2}$ but rather its historical aftermath, that is to say, the extraordinary affiliation between the Paradoxe, which adumbrates an aesthetic philosophy of histrionic dédoublement, and the concept of Romantic Irony, wherein the self-reflexivity of the comédien is embodied in the self-reflexive dimension of the literary artifact.

Our investigation takes as its philosophical basis Diderot's enquiries into the nature of the universe, which he understood to be in a constant process of fermentation, change, becoming:

Tout change, tout passe, il n'y a que le tout qui reste. Le monde commence et finit sans cesse; il est à chaque instant à son commencement et à sa fin; il n'en a eu jamais d'autre, et n'en aura jamais d'autre.

Dans cet immense océan de matière, pas une molécule qui ressemble à une molécule, pas une molécule qui se ressemble à elle-même un instant: "Rerum novus nascitur ordo," voilà son inscription éternelle. ${ }^{3}$

What we hope to demonstrate is that Diderot's ontological assumption of a dynamic universe, derived as it is from the Cartesian postulate 
of matter in motion, will have a profound significance for his aesthetic theories: indeed, the inward dynamism of the universe with its inherent emphasis on the potentiality of matter, finds its aesthetic counterpart in the immanent aesthetic artifact which is likewise in a state of dynamic fermentation. Just as there is no molecule in the universe which is identical unto itself, so likewise is there the impossibility of self-coincidence at the heart of Diderot's aesthetics: the non-coincidence of matter finds its aesthetic counterpart in the theory of selftranscendence - whether this be the histrionic parabasis of the comédien or the literary parabasis of the self-reflexive aesthetic artifact. Parabasis, which in its Attic form amounted to a disruption of the dramatic illusion, must be understood here as symbolic of the non-coincidence inherent in an organismic universe; as such it stands as the guarantor against stasis. ${ }^{4}$ The parabastic aesthetic object, which literally gainsays what is initially posited, must thus be perceived as essentially ironic: 'Dans l'ironie, l'homme anéantit, dans l'entité d'un même acte, ce qu'il pose. ${ }^{5}$ Hence, for Diderot, the irony of historical portraiture and the self-repudiation of his own portrait by Van Loo: the static solidification of one moment in history cannot capture the multivalency of disjunctive reality. The historical portraitist, on account of the heterogeneous nature of an organismic universe is, ipso facto, doomed to failure. In this respect the impuissance of historical portraiture in no way differs from the abortive attempt of literature to encode ambient reality. ${ }^{6}$

That the dualistic dynamics of Diderot's histrio should be founded on the notion of parabasis is abundantly clear in the Paradoxe: it is only in dissociating himself from his role and from himself that the actor can, paradoxically, incarnate his personage. It is at this point that we become aware of the ironic intent of Diderot's argument: for the mendacious histrio, like Sartrean man, is what he is not, and is not what he is. ${ }^{7}$ Diderot's argument is based significantly on the notion of dialectical interplay, for the histrio is, so to speak, suspended between his personnage and his author; he is likewise suspended between his existential being and his histrionic role: 'il y a trois modèles, l'homme de la nature, l'homme du poète, l'homme de l'acteur' (p. 376). The negative capability of the protean histrio who, like Keats's chameleon poet, exults in the dynamic potentiality of his suspended being, is perhaps best illustrated by Diderot's definition of the histrio as a pregnant nothingness ('le grand comédien est tout et n'est rien' [p. 341] ${ }^{8}$ ), at one and the same time capable of possessing himself ('il n'y a que l'homme qui se possède ... qui puisse ... déposer et reprendre son masque' [p. 336]), and yet the 'pantin merveilleux dont le poète tient la ficelle' (p. 348). Moreover, the histrio's kaleidoscopic interrelationships are further rein- 
forced by the fact that his art lies at the intersection of two symbolic media, language and gesture, the former in addition being further refracted by the fact that it too, for the purposes of the histrio, stands at another intersection - between the written and the oral.

Furthermore, Diderot's presentation of the histrio in terms of the fluid rapport of a dialectical moment is reinforced by the dialogic structure of his argument in which the digressive nature of the latter in fact undoes the original opposition of the two voices. Indeed, the dédoublement of the comédien is parallelled by the self-reflexive nature of the discourse, which proves as protean as its histrionic counterpart. First, it is of significance to note the opening paraleipsis of the Paradoxe, which is echoed in the open-ended structure of the 'conclusion.' The parameters of the argument are decidedly fluid. Nor can the basic argument of the Paradoxe be reduced simplistically, as some critics maintain, ${ }^{9}$ to two opposing voices: the conclusion, with its surprising intervention of the narrative voice clearly dramatizes the multiple perspectivism involved in the dialogic presentation - if indeed we can term dialogic what is, in many respects, monologic, the Second voice acting as stooge, so to speak, in order to allow the First to expound on various themes. It is likewise significant that the conclusion should reveal the dédoublement of the First voice in his dialogue with himself. It is curious to note that the latter's 'réflexion déplacée' (p. 363) may, in fact, be taken to symbolize the lateral exposition of the whole argument. The multi-faceted presentation of the latter, the chaotic aspect of which ironically belies the central thrust of the argument advocating the powers of reason as axial to the art of the histrio, thus echoes the presentation of the histrio as fluid rapport, as dialectical moment. Both are endowed with the fermentation and abundance, or what Schlegel terms the 'ewige Agilität,' of an organismic cosmos. ${ }^{10}$

The presentation of the histrio as fluid rapport is parallelled by the self-reflexive stance of Diderot's fiction which likewise attempts to delineate the dialectical moment of creation. Indeed, the histrio, for Diderot, is in no way distinguished from his literary counterpart: 'Et pourquoi l'acteur différerait-il du poète, du peintre, de l'orateur, du musicien?' (p. 309). If Diderot chooses the histrio as symbolic representative of the creative artist, it is on account of his unique relationship to his medium, that is to say he is his medium. Just as the histrio is presented in terms of his dialectical relationship with his aesthetic creation and his existential being, the literary artifact is, for Diderot, similarly dialectical in structure, the dialectical moment consisting of the literary text's fluid rapport with its author and fictive narrator and, simultaneously, with its reader - both actual and contrived. Histrionic selftranscendence thus finds its counterpart in literary self-transcendence 
when the 'Darstellende' ('the portrayer') becomes co-terminous with the 'Dargestellte' ('the portrayed'). ${ }^{11}$ Just as the histrio must insinuate himself into his role whilst simultaneously transcending it, so too the author of the self-reflexive text inscribes himself into his creation as a fictional character: whilst being a part of the fiction, the author nevertheless remains detached therefrom and indeed, by his very presence, negates the fiction he supposedly posits. Parabasis is here seen to be contiguous with paraleipsis and further confirms the inherent irony of the dialectical moment. ${ }^{12}$

The question of literary parabasis dealing with the problematics of creating a fictive illusion is perhaps best typified in Jacques le fataliste (1771-78), although the techniques of metafiction involved in the latter are also visible in earlier works, such as Les Bijoux indiscrets and L'Oiseau blanc, written some twenty-five years earlier. It is likewise significant to realize that the problematics of textual self-consciousness, that is to say the presentation of a problematic form of literature which, via its disaggregation, re-enacts the process by which it generates its meaning, can, as Terence Cave has amply illustrated, ${ }^{13}$ be traced back to the period of the Renaissance. Nor is Diderot alone amongst his contemporaries to have adopted this technique - witness Diderot's enthusiasm for Sterne's Tristram Shandy (1760-67).

The techniques of distanciation in Jacques le fataliste are multiple. Suffice it for our purposes to note the theatrical implications of the fluid, dialogic structure, onto which must be superimposed the theatrical perspective of the distanciation effected by both author and reader alike. It is not without reason that Jacques le fataliste may be termed Le Paradoxe sur le romancier. Paradoxical is the fact that the metafictional interpolations suspend the fiction they purport to affirm. Paradoxical is the fact that the author does not present facts, but rather the potentiality thereof. Paradoxical is the fact that the author, who presents himself as would-be demiurge ('Il ne tiendrait qu'à moi') ${ }^{14}$ is, in fact, 'determined' by his reader. ${ }^{15}$ Paradoxical too is the very address to the reader in a novel which was published posthumously and, hence, decidedly not for public consumption. Paradoxical also is the open-ended 'conclusion.' The quid pro quo of the fiction is clearly seen as contingent upon the existential quid pro quo, Diderot's ontological refutation of determinism being reflected in the ambiguities implicit in aesthetic determinism. The aesthetic artifact is, for Diderot, not a static entity, but rather a dynamic, mediating structure. We perceive once again that Heraclitean principle of perpetual flux which is at the heart of Diderot's ontological perception of the universe.

With the transition from the mechanistic to the organismic episteme, the traditional perception of language likewise underwent a momen- 
tous re-orientation. Kant's Copernican revolution postulating the primacy of the knowing subject over the known object severely undermined the classical postulate of a static, schematic approach to language: with the questioning of the possibility of objective knowledge, the automatic representative function of the word was superseded by a new dynamic potential. With the inevitable autonomy of the word, the accessibility of knowledge is, of necessity, drawn into question: man's faith in his epistemological capabilities cannot but be compromised by the new dynamic theory of semantics. Locke's Essay Concerning Human Understanding (1690) is perhaps the first modern treatise to deal with the new philosophy of language which postulates a linguistic relativism. ${ }^{16}$ The new epistemological orientation of semantics was likewise the subject of Condillac's Essai sur l'origine des connaissances humaines (1746).

Just as the dynamic potential of the protean histrio is grounded in the vacuity of his being, so too the linguistic symbol is endowed by Diderot with a negative capability. The literary artifact, as we have seen, must be perceived in terms of its kinesis, as a mobile system of interrelationships. Similarly language, as polysemic sign, will destabilize the literary artifact which can no longer lay claim to meaning: with the acceptance of linguistic relativism, meaning does not exist as a definable stasis, but is presented rather as a dynamic potential in its coming-to-be. The parabasis of histrionic and literary alterity thus finds its counterpart in the notion of linguistic alterity. Following in Locke's footsteps, Diderot is sceptical concerning the representational capacity of language: 'les mots ne sont et ne peuvent être que des signes approchés d'une pensée, d'un sentiment, d'une idée' (Paradoxe, p. 304). Words cannot, as Diderot laments in the Paradoxe, be endowed with a universal meaning: 'Pesez bien ce qui suit, et concevez combien il est fréquent et facile à deux interlocuteurs, en employant les mêmes expressions, d'avoir pensé et de dire des choses tout à fait différentes' (p. 306). The essential ambivalence of the word as symbolic referent can perhaps best be understood by comparison with the ambiguous relationship of the histrio to his medium: both must disappear, must dematerialize themselves in order to complete their function: the word as means disappears once the evocation of the real has been accomplished. Furthermore, to the extent that the art of the histrio is grounded in language, the asymptotic relationship of words to things adds a further level of distanciation to the latter. The gulf separating thought and expression is indeed a constant in Diderot's oeuvre. In La Lettre sur les sourds et muets (1751), Diderot's critique of language as an adequate medium for the expression of man's thinking ('l'esprit ne va pas à pas comptés comme l'expression'17) is presented in terms of the kinetic 
capacities in man's soul: 'Notre âme est un tableau mouvant d'après lequel nous peignons sans cesse: nous employons bien du temps à le rendre avec fidélité; mais il existe en entier et tout à la fois' (Ibid.). Does not Jacques too complain of the incapacity of language to translate his mobile thought: 'Ah, si je savais dire comme je sais penser! Mais il était écrit là-haut que j'aurais les choses dans ma tête, et que les mots ne me viendraient pas. ${ }^{18}$ The implicit refutation of linguistic determinism must here be perceived as the necessary counterpart of Diderot's refutation of ontological and aesthetic determinism. If language is, as Diderot would appear to suggest, an intrinsically flawed medium incapable of translating meaning ('Notre discours est toujours en deçà ou au-delà de la sensation'19), the very foundation of the literary artifact is thereby drawn into question. The relativization of the literary artifact via Diderot's theory of scriptural hermeneutics carries with it the seeds of aesthetic self-contestation. As the literary artifact can only come into being in and through the medium of language, what Diderot is proposing thereby is nothing less than Le Paradoxe sur la littérature.

An organismic theory of literature likewise based on the notion of histrionic parabasis will be seen to be at the core of Schlegel's theory of Romantic Irony. First, it is important to underscore Diderot's enthusiastic reception in the world of German ideas ${ }^{20}$ and, more particularly, Schlegel's own appreciation of the parabastic quality of Diderot's Jacques le fataliste: 'Wenn Diderot im Jakob etwas recht Genialisches gemacht hat, so kömmt er gewöhnlich gleich selbst hinterher und erzählt seine Freude dran, dass es so genialisch geworden ist.' ${ }^{21}$ ('When Diderot does something really brilliant in his Jacques, he usually follows it up by telling us how happy he is that it turned out so brilliantly.') From Schlegel's fragmentary notations, we would understand Romantic Irony to be a mode of consciousness which attempts to come to grips with man's incomplete understanding of a relative cosmos. It translates an epistemological, an ontological and an aesthetic response to the chaotic universe of a post-mechanistic era: or, to be more precise, it attempts to translate the artist's dialectical response to the chaotic abundance (what Schlegel terms 'Fülle') of a non-absolute universe by the paradoxical creation of a relative, progressive text, endlessly flowing from creation to decreation in a state of never-ending becoming and limitless freedom, whereby the artist hovers perpetually between enthusiastic self-creation (what Schlegel terms 'Selbstschöpfung') and ironic self-destruction ('Selbstvernichtung'). ${ }^{22}$ Romantic Irony is then essentially a 'beautiful self-mirroring' ('schöne Selbstbespiegelung $\left.{ }^{\prime}\right)^{23}$ which reflects the act of creation as present and presence, as reflection and reflexion, as poetry and the poetry of poetry 
('Poesie der Poesie'). ${ }^{24}$ The histrionic character of Romantic Irony, that is to say its essential parabasis, is most clearly brought out in Schlegel's 42nd Lyceum Fragment.

Es gibt alte und moderne Gedichte, die durchgängig im Ganzen und überall den göttlichen Hauch der Ironie atmen. Es lebt in ihnen eine wirklich transzendentale Buffonerie.

(There are ancient and modern poems which breathe, in their entirety and in every detail, the divine breath of irony. In such poems there lives a real transcendental buffoonery.)

Transcendental buffoonery implies, as Schlegel goes on to explain, a quality of mind ('die Stimmung welche alles übersieht' ['the mood which surveys everything']) which permits the artist to transcend his creation and even his own genius ('und sich über alles Bedingte unendlich erhebt, auch über die Kunst, Tugend oder Genialität' ['and rises infinitely above everything limited, even above art, virtue and genius']). It is for this reason that it is intrinsically histrionic in form ('im Äussern, in der Ausführung die mimische Manier eines gewöhnlichen, guten, italienischen Buffo' ['in their exterior form, by the histrionic style of an ordinarily good Italian Buffo']). With Romantic Irony, we are confronted with a revolutionary mode of aesthetic expression wherein mimetic representation is superseded by aesthetic re-presentation, as the parabastic text, after the manner of Diderot's histrio, attempts a metacomment upon itself qua text as dialectical moment: a momentous aesthetic shift has taken place whereby the work of art no longer strives after mimetic representation, but reflects rather itself and what constitutes its fictitiousness.

The impossibility of self-coincidence both within the actor and the literary text bespeaks not only the tragic limitations of parabastic art, but indeed of all epistemological enquiry. 'Knowledge,' writes Santayana in his analysis of the German mind, 'is impossible. You know only your so-called knowledge, which itself knows nothing, and you are limited to the autobiography of your illusions. ${ }^{25}$ The disenchanted conclusion of the Éléments de physiologie (1774) lamenting the impenetrability of man to himself, to others, and above all to knowledge, might stand as Diderot's sceptical confession of the chaos of relativity:

Qu'aperçois-je? Des formes, et quoi encore? des formes, j'ignore la chose. Nous nous promenons entre des ombres, ombres nous-mêmes pour les autres et pour nous. ${ }^{26}$

Like Jacques, 'nous marchons dans la nuit.' 
Having outlined the essential kinesis, mutability and open-endedness of parabastic art, we can only offer a conclusion which itself emphasizes self-transcendence and thereby defies closure: aesthetic aporia cannot, by definition, be circumscribed. Does the paradox of Romantic Irony not imply, in the final analysis, the necessity and impossibility of all conclusions?

Andre Dichtarten sind fertig, und können nun vollständig zergliedert werden. Die romantische Dichtart ist noch im Werden; ja ist ihr eigentliches Wesen, dass sie ewig nur werden, nie vollendet sein kann. ${ }^{27}$

(Other types of poetry are completed and can now be entirely analyzed. The Romantic type of poetry is still becoming; indeed, its peculiar essence is that it is always becoming and that it can never be completed.)

However, although not susceptible to rational discourse, the dialectical moment of a mediating structure can perhaps be transcribed in symbolic language. The self-consuming nature of parabastic art thus finds its allegorical counterpart in the myth of the uroboros, the serpent which bites its own tail. The uroboros, whilst seemingly devouring itself, in fact does not represent so much the act of devouring, but rather its virtuality, that is to say the potentiality of the act which, if completed, would annihilate the very symbol: 'Il est à chaque instant à son commencement et à sa fin.' Symbolizing as it does the paradox of static movement, the uroboros aptly corresponds to the dialectical moment of parabastic art which, very literally, consumes its own tale.

\section{JUDITH SPENCER}

Camrose Lutheran College

\section{Notes}

1 J.-P. Sartre, Qu'est-ce que la littérature? (Paris: Gallimard, 1948), p. 148.

2 An analysis of the supremacy of reason over emotion, intellect over sensibility, in acting was a topic which had already been debated by St. Albine and Riccoboni some ten years prior to Diderot's Paradoxe.

3 From Le Rêve de d'Alembert, quoted by A. Grava, 'Diderot and Recent Philosophical Trends,' Diderot Studies, IV (Genève: Droz, 1963), p. 99. 
4 Originally parabasis referred to the convention in Attic comedy whereby the chorus, at the mid-point in the play, would address itself directly to the audience in order to comment on the drama, thus suspending the dramatic illusion. However, even plays having a full parabasis in the centre might have a shorter second parabasis towards the end. It might also be used, as is the case with Aristophanic parabasis, as a form of self-advertisement, for extolling the merits of the poet himself whilst denigrating his rivals. The parabasis has a recognizable structure, each part having its particular function; it is constituted of the following elements: 1) the valediction 2) the 'anapaests' 3) the 'ode' 4) the 'epirrhema' 5) the 'antode' 6) the 'antepirrhema.' The parabasis might also, on occasion, be endowed with didactic intent, the comic poet, whether he addressed the audience in propria persona or from some other definable standpoint, using it as a medium for offering advice and admonition to the audience (Cf. J.K. Dover, Aristophanic Comedy [Berkeley and Los Angeles: University of California Press, 1972], pp. 49-65). Whilst I use the term parabastic art to refer generally to the notion of the rupture of fictive illusion, it is perhaps necessary at this point to qualify this statement. The classical parabasis is of a defined structure, occurring at a pre-allotted moment within the development of the play: parabastic art, however, in its more modern formulation, is in fact an element permeating the fabric of the entire fiction and thus co-terminous with it as a whole. For a discussion of authorial parabasis in Schlegel and Diderot, cf. S. Mautner, 'The Story of the Comprised Author: Parabasis in Friedrich Schlegel and Denis Diderot,' Comparative Literature Studies, XVI, No. 1 (March, 1979), pp. 21-32.

5 J.-P. Sartre, L'Être et le néant (Paris: Gallimard, 1943), p. 85.

6 The self-transcendence inherent in the aesthetic artifact finds its counterpart in the art history of the Eighteenth Century, at which time there occurs in painting a shift in perspectivism whereby autotelic hermeticism is superseded by the assumption of a fundamental relationship between painting and beholder. Cf. M. Fried, Absorption and Theatricality: Painting and Beholder in the Age of Diderot (Berkeley and London: University of California Press, 1980).

7 In the conclusion to the Paradoxe (Diderot: Oeuvres esthétiques, ed. P. Vernière [Paris: Garnier, 1959], p. 381), 'imiter,' 'simuler' and 'feindre' are the epithets used by Diderot to describe the art of the histrio. All further references to the Paradoxe will be from this edition.

8 The First's response to this statement brings out clearly the aforementioned Keatsian affinities: 'Et peut-être est-ce parce qu'il n'est rien qu'il est tout par excellence, sa forme particulière ne contrariant jamais les formes étrangères qu'il doit prendre' (p. 341).

9 L. Gossman and E. MacArthur, 'Diderot's displaced Paradoxe' in Diderot: Digression and Dispersion: A Bicentennial Tribute (Lexington, Kentucky: French Forum, 1984), pp. 106-20.

10 F. Schlegel, Ideen 69, Kritische Ausgabe, vol. ii, ed. H. Eichner (Munich - Vienna - Paderborn: Schöningh, 1967), p. 263.

11 F. Schlegel, Athenäum Fragment, 116.

12 N. Knox (The Word Irony and its Context, 1500-1755 [Durham, North Carolina: Duke University Press, 1961], p. 13) points out that the rhetorical device called praeteritio (the Latin term for the Greek paraleipsis) was called irony in the 
rhetorics of Quintilian, Abraham Fraunce, John Smith, Hobbes and Anthony Blackwall.

13 Cf. T. Cave, The Cornucopian Text: Problems of Writing in the French Renaissance (Oxford: Clarendon, 1979). H. Cohen ('La Figure dialogique dans Jacques le fataliste,' Studies on Voltaire and the Eighteenth Century, ed. T. Besterman, CLXII [Oxford: Voltaire Foundation, 1976], pp. 23, 157, 158), on the other hand, tends to view Diderot's logical antecedents as dating from the Seventeenth Century with such authors as Furetière and Scarron. Cf. also in this context: 1) S. Fish, Self-Consuming Artifacts: The Experience of Seventeenth-Century Literature (Berkeley: University of California Press, 1972), where is analyzed the dialectical process inherent in the dynamics of the reading experience, which makes of the literary artifact a kinetic object which ultimately defies closure; 2) P. Parker, Inescapable Romance: Studies in the Poetics of a Mode (New Jersey: Princeton University Press, 1979) - which is devoted to the problematics of closure in the romance form and proposes a dialectics of projection and postponement; 3) L. Hutcheon, Narcissistic Narrative: The Metafictional Paradox (Waterloo: Wilfrid Laurier U.P., 1980).

14 Jacques le fataliste et son maitre, ed. Y. Belaval, (Paris: Gallimard, 1973), p. 36.

15 The paradoxical situation of the literary demi-urge may be compared with the paradoxical nature of the histrio whose reasoned control over his role is counter-balanced by his possession by the latter ('c'est l'esprit d'un autre qui le domine' [p. 362]).

16 For a detailed discussion of the mechanistic and relativistic models of linguistics, cf. L. Furst. Fictions of Romantic Irony in European Narrative, 1760-1857 (London: MacMillan, 1984), pp. 39-42.

17 Quoted by H. Cohen, op. cit., p. 116.

18 Ibid., p. 188.

19 Le Rêve de d'Alembert in Diderot: Oeuvres philosophiques, ed. P. Vernière, p. 370.

20 R. Mortier, 'La Réaction allemande aux premières ouvres philosophiques de Diderot,' Diderot Studies, IV (1963), pp. 131-51.

21 F. Schlegel, Schriften zur Literatur, ed. W. Rasch ( Munich: Deutscher Taschenbuch Verlag, 1970), p. 7.

22 F. Schlegel, Athenäum Fragment, 51.

23 Ibid., 238.

24 Loc. cit.

25 G. Santayana, The German Mind: A Philosophical Diagnosis (New York: Cromwell, 1968), p. 15.

26 Diderot: Oeuvres complètes, ed. R. Lewinter, XIII, pp. 822-23.

27 F. Schlegel, op. cit., 116. 